\title{
PENGARUH MODEL PEMBELAJARAN BERBASIS MASALAH DENGAN MENGGUNAKAN ANIMASI MACROMEDIA FLASH TERHADAP HASIL BELAJAR SISWA PADA MATERI POKOK GERAK LURUS DI KELAS X SMA
}

\author{
'Raminah dan Mara Bangun Harahap \\ Jurusan Fisika FMIPA Universitas Negeri Medan \\ Nataraminah@gmail.com
}

\begin{abstract}
ABSTRAK
Penelitian ini bertujuan untuk mengetahui pengaruh model pembelajaran berbasis masalah dengan menggunakan animasi makromedia flash terhadap hasil belajar siswa pada materi pokok Gerak Lurus di kelas X SMA Negeri 11 Medan T.P. 2014/2015.Jenis penelitian ini adalahkuasi eksperimen. Populasi dalam penelitian ini adalah seluruh siswa kelas XSMA yang terdiri dari lima kelas. Sampel penelitian ini diambil dua kelas yaitu kelas X MIA-2(sebagai kelas eksperimen) dan kelas X MIA-1 (sebagai kelas kontrol) yang masing-masing berjumlah 40 siswa yang ditentukan dengancluster random sampling. Kemudian diberikan perlakuan yang berbeda yaitu kelas eksperimen dengan model pembelajaran berbasis masalah dengan menggunakan animasi makromedia flash dan kelas kontrol dengan pembelajaran konvensional. Sebelum diberikan perlakuan, terlebih dahulu dilakukan uji normalitas dan uji homogenitas. Data yang digunakan dalam penelitian ini adalah tes essai, jumlah soal 8 item yang telah dinyatakan valid oleh validator.Berdasarkan hasil penelitian diperoleh nilai rata-rata postes siswa pada kelas eksperimen lebih tinggi dibandingkan kelas kontrol. Hasil observasi menunjukkan bahwa nilai aktivitas dan keterampilan siswa pada kelas eksperimen diperoleh cukup baik sedangkan nilai aktivitas siswa pada kelas kontrol diperoleh kurang baik. Melalui uji hipotesis satu pihak diperoleh bahwa pengaruh model pembelajaran berbasis masalah dengan menggunakan animasi makromedia flash terhadap hasil belajar siswa lebih tinggi daripada pembelajaran konvensional.
\end{abstract}

KataKunci: Pembelajaran Berbasis Masalah, Gerak Lurus, Animasi Makromedia Flash, Hasil Belajar Siswa. 


\section{PENDAHULUAN}

Fisika merupakan salah satu objek mata pelajaran IPA yang menarik dan sangat penting untuk dipelajari oleh setiap peserta didik agar menumbuhkan kemampuan berfikir secara ilmiah. Sains fisika merupakan suatu ilmu pengetahuan bersifat ilmiah yang memerlukan pemahaman dan melakukan penyelidikan/percobaan agar mampu memahami dan menguasai konsep sehingga dapat mengaplikasikannya dalam pemecahan masalah kehidupan sehari-hari. Pendidikan fisika yang diselenggarakan di sekolah bertujuan agar siswa memahami konsep, memahami terjadinya suatu peristiwa dan fenomena alam secara ilmiah, dan dapat menerapkan ilmu fisika dalam kehidupan sehari-hari. Berdasarkan hasil observasi yang dilakukan oleh peneliti di SMA Negeri 11 Medan dengan menggunakan instrumen angket diperoleh sejumlah data dari 40 siswa, menunjukkan bahwa rasa percaya diri siswa dalam pembelajaran fisika hanya mencapai $65.95 \%$, ketertarikan siswa terhadap pelajaran fisika hanya $60.38 \%$, perhatian siswa terhadap pembelajaran fisika $64,75 \%$, dan kegemaran siswa terhadap pelajaran fisika hanya $61.48 \%$. Dari hasil persentase dikatakan bahwa sikap siswa terhadap pembelajaran fisika masih sangat kurang baik sehingga menimbulkan rendahnya hasil belajar fisika siswa.

Salah satu penyebab terjadinya masalah dalam pembelajaran fisika di SMA Negeri 11 Medan adalah guru belum menerapkan model pembelajaran yang bervariasi, guru menerangkan di depan kelas dan siswa mendengar, mencatat dan mengerjakan soal. Pembelajaran dilaksanakan cenderung berpusat pada guru (teacher centered) yang hanya memfokuskan pada rumusrumus fisika dan mengutamakan perhitungan bukan menjelaskan konsep dasar dan hubungan pelajaran fisika dengan kehidupan sehari-hari.

Sesuai dengan hasil wawancara yang dilakukan oleh peneliti dengan seorang guru fisika SMA Negeri 11 Medan, mengemukakan bahwa belum menerapkan model pembelajaran secara variasi, guru menggunakan model pembelajaran konvensional (pembelajaran langsung) dan kurangnya pemanfaatan media saat proses pembelajaran. Model konvensional merupakan model pembelajaraan yang umum dipakai oleh guru dengan mengunakan metode ceramah, tanya jawab, dan penugasan. Model pembelajaran konvensional lebih banyak berpusat pada guru yang menyebabkan siswa pasif dan membuat siswa merasa bosan sehingga siswa kurang tertarik terhadap materi yang diajarkan. Situasi pembelajaran dengan menggunakan model yang biasa diterapkan oleh guru menyebabkan kurangnya partisipasi dan minat belajar siswa terhadap pelajaran fisika yang berdampak pada hasil belajar fisika siswa.

Berdasarkan permasalahan di atas dilakukan salah satu upaya untuk menciptakan pembelajaran fisika yang menarik dan menyenangkan yang melibatkan semua siswa secara aktif dalam kegiatan pembelajaran dengan tujuan menarik perhatian dan minat belajar siswa serta 
meningkatkan hasil belajar fisika siswa. Salah satu alternatif yang dapat digunakan untuk mengatasi kesulitan siswa dalam belajar adalah dengan menciptakan suasana pembelajaran yang langsung berhubungan dengan kehidupan sehari-hari dan dapat memahami berbagai konsep yang diajarkan, sehingga siswa dapat menggunakan dan mengingat konsep fisika lebih lama. Model pembelajaran berbasis masalah adalah salah satu upaya solusinya, model pembelajaran berbasis masalah dirancang dengan tujuan untuk membantu siswa mengembangkan kemampuan berfikir danmengembangkan kemampuan dalam memecahkan masalahkehidupan sehari-hari (Arends, 2008).

Model pembelajaran berbasis masalah merupakan suatu model pembelajaran yang didasarkan pada permasalahan yang membutuhkan penyelidikan autentik yakni penyelidikan yang membutuhkan penyelesaian nyata dari permasalahan yang nyata, sehingga memungkinkan siswa memahami konsep fisika bukan sekedar menghafal konsep (Trianto, 2009).

Menurut Arends (2008:4), Esensi pembelajaran berbasis masalah berupa menyuguhkan berbagai situasi bermasalah yang autentik dan bermakna kepada siswa, yang berfungsi sebagai landasan bagi investigasi dan penyelidikan siswa. Dengan kata lain, dapat dikatakan bahwa model pembelajaran berbasis masalah bukan hanya sekedar model pembelajaran yang diarahkan agar peserta didik dapat mengingat dan memahami berbagai data, fakta atau konsep, akan tetapi bagaimana data, fakta, dan konsep tersebut dapat dijadikan sebagai alat untuk melatih kemampuan berpikir siswa dalam menghadapi dan memecahkan suatu permasalahan.

Model pembelajaran berbasis masalah telah diteliti oleh peneliti sebelumnya, seperti Yustina (2009) dan Pohan (2012). Hasil penelitian Yustina menunjukkan bahwa terdapat peningkatan hasil belajar siswa setelah diterapkan model pembelajaran berdasarkan masalah, sedangkan Pohan menemukan bahwa model pembelajaran berbasis masalah secara signifikan memberikan pengaruh lebih baik dibandingkan dengan model pembelajaran konvensional. Adapun kelemahan dalam penelitian ini adalah kurang memperhatikan dalam pengelolaan waktu yang cukup bagi siswa untuk terlibat secara mendalam dalam kegiatan pembelajaran, selain itu model ini tidak sesuai dengan kebanyakan informasi atau pengetahuan yang harus dipelajari karena guru masih banyak yang tidak memanfaatkan penggunaan model ini. Oleh karena itu peneliti akan lebih mengoptimalkan alokasi waktu untuk setiap pembelajaran. Selain itu peneliti juga akan menggunakan media dalam proses belajar mengajar. Kehadiran media dalam proses belajar mengajar mempunyai arti yang cukup penting. Karena dalam kegiatan pembelajaran ketidakjelasan bahan yang disampaikan dapat dibantu dengan menghadirkan media sebagai perantara (Djamarah, 2006). Dalam hal ini peneliti akan memaksimalkan hasil belajar siswa dengan menggunakan media 
animasi makromedia flash, karena media animasi bisa menampilkan gambar statisyang bergerak dan bersuara serta dapat menampilkan simbol yang jelas, lengkap dan mudah untuk membuat informasi lebih mudah dimengerti dan diingat kembali sehingga memudahkan siswa dan guru dalam proses pembelajaran di kelas dengan meringkas bahan, merumuskan masalah-masalah yang akan disajikan dan dapat mudah diingat.

Berdasarkan masalah di atas, penulis ingin melakukan penelitian yang berjudul "Pengaruh Model Pembelajaran Berbasis Masalah Dengan Menggunakan Animasi Macromedia Flash Terhadap HasilBelajar Siswa Pada Materi Pokok Gerak Lurus Di Kelas X SMA."

\section{METODE PENELITIAN}

Penelitian ini dilaksanakan di SMA Negeri 11 Medan kelas X Semester I T.P. 2014/2015, yang beralamat di Jl. Pertiwi No. 93 Kecamatan Medan Tembung. Waktu penelitian dilaksanakan pada bulan September 2014 semester I T.P. 2014/2015. Populasi dalam penelitian ini adalah seluruh siswa kelas X SMA Negeri 11 Medan yang terdiri dari lima kelas. Menentukan sampeldiambil dengan cluster random sampling yang mewakili populasi. Sampel terdiri dari dua kelas, yaitu kelas X-MIA² sebagai kelas eksperimen dengan menggunakan model pembelajaran berbasis masalah dan kelas XMIA $^{1}$ sebagai kelas kontrol dengan model pembelajaran konvensional.

Jenis penelitian ini termasuk penelitian kuasi eksperimen. Penelitian ini melibatkan dua kelas yang diberi perlakuan yang berbeda.
Satu kelas dijadikan kelas eksperimen dan satu kelas dijadikan kelas kontrol. Desain penelitian menggunakan desain two group pretest-postest designuntuk mengetahui hasil belajar siswa dengan memberikan tes pada kedua kelas sebelum dan sesudah diberi perlakuan.Desain penelitian ini ditunjukkan pada Tabel 1.

Tabel 1.Two Group Pretest-Postest Design

\begin{tabular}{|c|c|c|c|}
\hline Kelas & Pretes & Perlakuan & Postes \\
\hline Eksperimen & $\mathrm{T}_{1}$ & $\mathrm{X}_{1}$ & $\mathrm{~T}_{2}$ \\
\hline Kontrol & $\mathrm{T}_{1}$ & $\mathrm{X}_{2}$ & $\mathrm{~T}_{2}$ \\
\hline
\end{tabular}

Keterangan :

$\mathrm{T} 1=$ Pretes di berikan kepada kelas eksperimen dan kelas kontrol sebelum perlakuan.

$\mathrm{T} 2=$ Postes di berikan setelah perlakuan pada kelas eksperimen dan kelas kontrol.

$\mathrm{X}=$ Pengajaran dengan menerapkan model pembelajaran berbasis masalah.

$\mathrm{Y}=$ Pengajaran dengan menerapkan pembelajaran konvensional.

$\mathrm{T} 1$ = $\mathrm{T} 2$ (soal pretes sama dengan soal postes).

Instrumen yang digunakan dalam penelitian ini adalah tes hasil belajar siswa dalam bentuk essai berjumlah 8 soal. Tes hasil belajar terlebih dahulu distandarisasi dengan menggunakan uji validitas isi oleh dua orang dosen sesuai dengan pakar ahlinya. Setelah data pretes diperoleh, dilakukan analisis data dengan uji normalitas dengan uji Lilliefors dan uji homogenitas dengan uji kesamaan varians. Setelah itu dilakukan pengujian hipotesis uji dua pihak untuk mengetahui kemampuan awal siswa 
pada kedua kelompok sampel. Selanjutnya peneliti mengajarkan materi pelajaran dengan menggunakan model pembelajaran berbasis masalah dengan menggunakan animasi Macromedia Flash pada kelas eksperimen dan pembelajaran konvensional pada kelas kontrol. Untuk mengetahui perbedaan hasil akhirnya maka dilakukan postes menggunakan uji hipotesis untuk mengetahui pengaruh perlakuan model pembelajaran berbasis masalah dengan menggunakan animasi Macromedia Flash terhadap hasil belajar siswa.

\section{HASIL DAN PEMBAHASAN Hasil Penelitian}

Data yang dideskripsikan pada penelitian ini meliputi data hasil belajar fisika pada materi gerak lurus, yang diberikan perlakuan berbeda yaitu model pembelajaran berbasis masalah dengan menggunakan animasi Macromedia Flashdan model pembelajaran konvensional.Hasil belajar distribusi frekuensi data pretes siswa kelas eksperimen dan kontrol dapat divisualisasikan dalam diagram batang seperti pada Gambar 1.

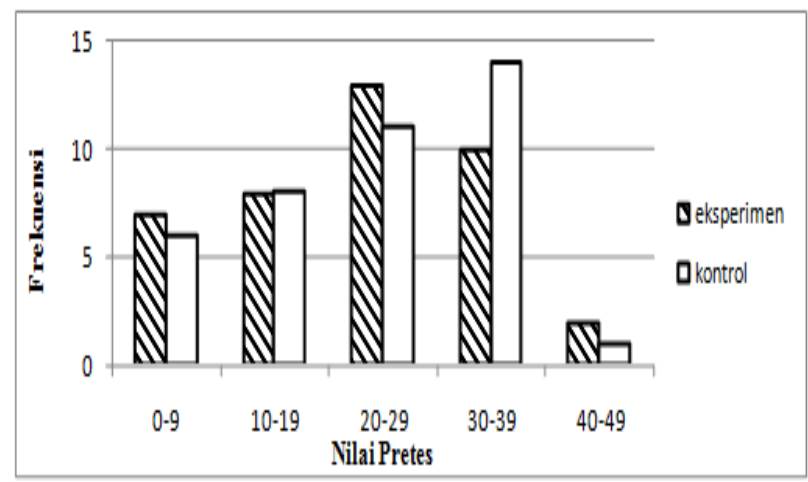

Gambar 1. Diagram Nilai Pretes
Diagram batang menunjukkan bahwa nilai pretes pada kelas eksperimen dan kelas kontrol memiliki nilai yang sangat rendah namun nilai kelas kontrol sedikit lebih tinggi dibandingkan dengan kelas eksperimen. Perbandingan rata-rata nilainya adalah nilai ratarata kelas kontrol yaitu 19,62 sedangkan nilai rata-rata kelas eksperimen yaitu 18,12.

Distribusi frekuensi data postes siswa kelas eksperimen dan kontrol dapat divisualisasikan dalam diagram batang hasil postessiswa kelas eksperimen dan kontrol seperti ditunjukkan pada Gambar 2.

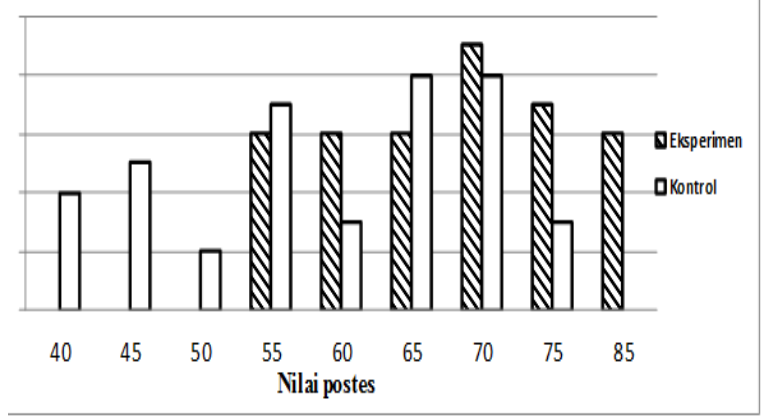

Gambar 2. Diagram Nilai Postes

Gambar 2menunjukkan bahwa nilai postes kelas eksperimen lebih tinggi dari pada nilai postes kelas kontrol, perbandingan rata-rata nilainya adalah 68,62dan 59,00. Terdapat peningkatan hasil belajar yang diperoleh pada kedua kelas, tapi hasil belajar di kelas eksperimen lebih tinggi dibanding kelas kontrol. Dengan demikian hasil belajar kelas eksperimen lebih baik dibandingkan dengan hasil belajar kelas kontrol.

Selain dari nilai pretes dan postes hasil belajar juga dapat 
dilihat dari penilaian aktivitas dan keterampilan. Penilaian aktivitas ini dilakukan oleh observer selama kegiatan belajar mengajar berlangsung oleh peneliti yang telah dilengkapi lembar penilaian aktivitas. Adapun aspek yang dinilai adalah: kerjasama, mengemukakan pendapat, komunikatif, menghargai pendapat orang lain. Aspek-aspek tersebut diberi skor 1 sampai 4 dengan pedoman pada lembar observasi aktivitassiswa. Kemudian pada penilaian keterampilanaspek yang dinilai adalah : menggunakan alat,merangkai percobaan dan membaca hasil percobaan. Untuk melihat hasil perkembangan dari aktivitassiswa pada kedua kelas dapat ditunjukkan pada diagram batang seperti ditunjukkan pada Gambar 3 dan Gambar 4.

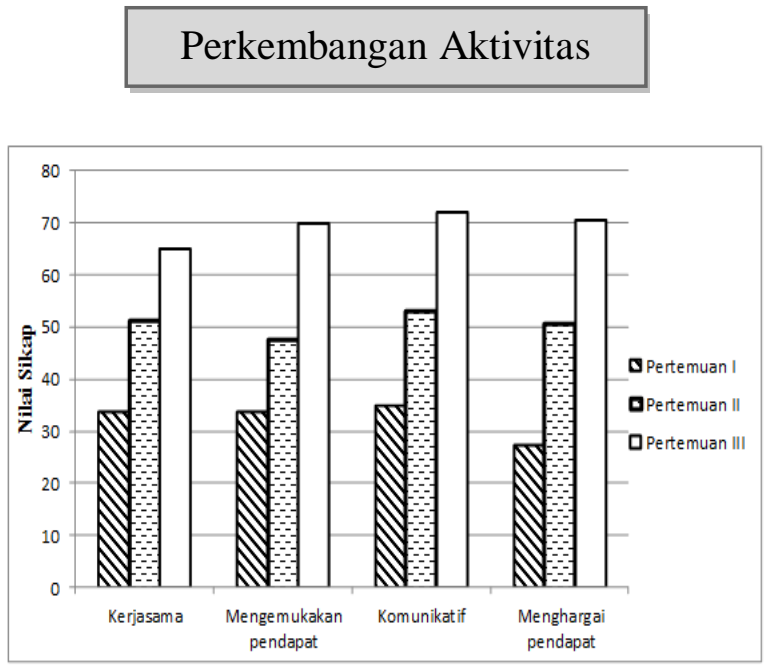

Gambar 3. Diagram Aktivitas KelasEksperimen

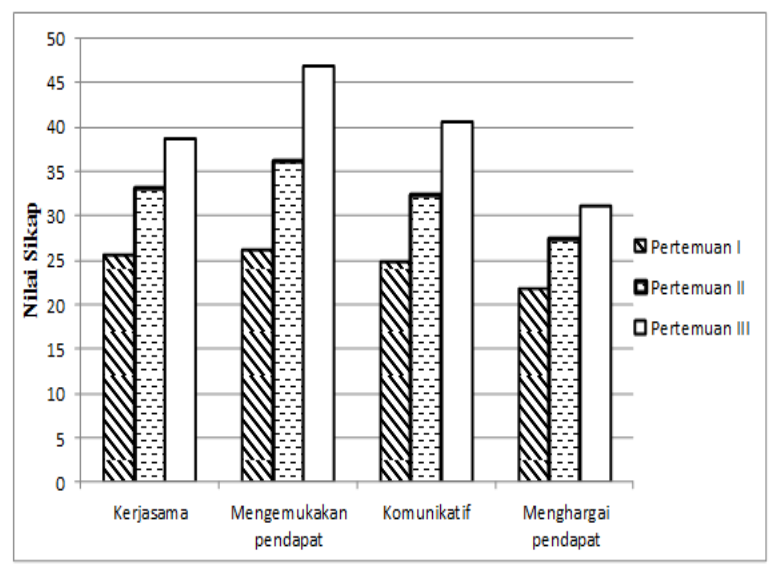

Gambar 4. Diagram AktivitasKelas Kontrol

Berdasarkan diagram batang di atas menunjukkan bahwa nilai aktivitas siswa dikelas eksperimen lebih baik daripada kelas kontrol, yaitu nilai aktivitas pada kelas eksperimen pada pertemuan I, II persentasenya masih termasuk kategori sangat kurang (persentase 0\%-54\%), sedangkan pada pertemuan III persentasenya sudah meningkat menjadi cukup baik (persentase 65\%-74\%). Pada kelas kontrol pada pertemuan I,II dan III persentasenya dalam kategori sangat kurang (persentase 0\%-54\%). Hal ini disebabkan pada kelas eksperimen yang menggunakan model pembelajaran berbasis masalah memiliki fase-fase yang bisa meningkatkan perkembangan aktivitas siswa.

Hasil perkembangan dari keterampilan siswa pada kelas eksperimen dapat ditunjukkan pada diagram batang seperti ditunjukkan pada Gambar 5. 
Perkembangan Keterampilan

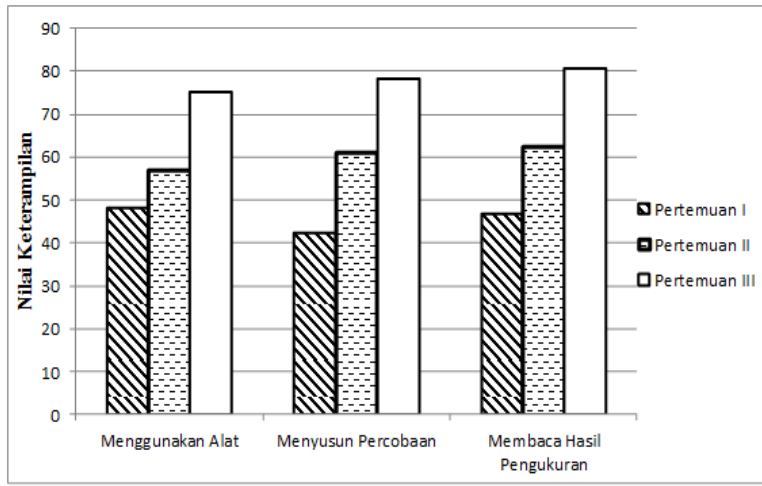

Gambar 5. Diagram

KeterampilanKelasEksperimen

Berdasarkan diagram batang di atas menunjukkan bahwa setiap pertemuan nilai keterampilan siswa mengalami peningkatan, yaitu pada pertemuan I masih dalam kategori sangat kurang (persentase 0\%-54\%), pada pertemuan ke II meningkat menjadi kategori kurang baik (persentase 55\%-64\%), dan pada pertemuan ke III nilai keterampilan siswa menjadi baik (persentase $75 \%$ 84\%). Hal ini disebabkan pada model pembelajaran di kelas eksperimen langsung melakukan percobaan untuk memecahkan masalah,sehingga siswa akan terampil menggunakan alat ukur,merangkai percobaan dan membaca hasil percobaan. Hal ini sejalan dengan apa yang dikatakan oleh Arends (2008),"Kolaboratif siswa dalam PBL mendorong penyelidikan dan dialog bersama dan pengembangan keterampilan berpikir dan keterampilan sosial".

\section{Pembahasan}

Hasil penelitian menunjukkan bahwa di kelas eksperimen yang diajar dengan menggunakan model pembelajaran berbasis masalah terjadi peningkatan hasil belajar,dimana nilai rata-rata pretesnya 18,12 sedangkan nilai rata-rata postes adalah 68,62 . Hasil penelitian menunjukkan bahwa peningkatan hasil belajar didukung oleh aktivitas siswa dalam proses pembelajaran. Keterkaitan hasil belajar dengan aktivitas siswa ditunjukkan dari peningkatan nilai rata-rata aktivitas siswa pada kelas eksperimen pada setiap pertemuan dengan nilai rata-rata pada pertemuan pertama yaitu $32,53 \%$, pertemuan kedua yaitu $50,63 \%$ dan pada pertemuan ketiga yaitu 69,38\%. Aktivitas siswa kelas eksperimen pada pertemuan pertama siswa tidak begitu aktif, tapi pada pertemuan kedua dan ketiga mengalami peningkatan. Hal ini disebabkan karena pada saat proses belajar mengajardengan menggunakan model pembelajaran berbasis masalah siswa dilibatkan secara aktif dalam proses pembelajaran. Siswa dituntut untuk mengembangkan kemampuan berpikir ketika disajikan suatu permasalahan dan adanya interaksi yang terjadi antar siswa maupun antara siswa dengan guru yang melatih kemampuan berkomunikasi, seperti yang terlihat ketika diskusi di kelas terjadi interaksi tanya jawab dan siswa bebas mengeluarkan pendapatnya masing-masing. Pernyataan peneliti sejalan dengan pendapat Arends (2008:41), bahwa esensi pembelajaran berbasis masalah berupa menyuguhkan berbagai situasi bermasalah yang autentik dan bermakna kepada siswa sehingga dapat memberikan kesempatan pada siswa bereksplorasi untuk mengumpulkan 
dan menganalisis data dalam memecahkan masalahdan dapat membantu siswa untuk mengembangkan keterampilan berpikir dan keterampilan mengatasi masalah, mempelajari peran-peran orang dewasa dan menjadi pelajar yang mandiri. Penerapan pembelajaran berbasis masalah dapat mendorong siswa untuk melakukan diskusi bersama untuk mengembangkan keterampilan berpikir dan keterampilan sosial.

Siswa di kelas kontrol yang diajar dengan menggunakan pembelajaran konvensional terjadi peningkatan hasil belajar, dimana nilai rata-rata pretesnya 19,62 , sedangkan nilai rata-rata postesnya adalah 59,00. Besarnya peningkatan hasil belajar di kelas kontrol ini masih lebih rendah jika dibandingkan dengan kelas eksperimen yang menggunakan model pembelajaran berbasis masalah. Hal ini disebabkan karena di kelas kontrol dengan pembelajaran konvensional ini hanya menyampaikan informasi dengan lisan kepada sejumlah siswa. Kegiatan ini berpusat pada penceramah dan komunikasi yang searah. Pada model pembelajaran konvensional, siswa belajar lebih banyak mendengarkan penjelasan di depan kelas dan melaksanakan tugas jika diberikan latihan soalsoal kepada siswa. Perkembangan aktivitas pada kelas kontrol tidak begitu aktif. Perkembangan aktivitas di kelas kontrol juga mengalami peningkatan dalam setiap pertemuannya, namun perkembangannya tidak sebesar perkembangan di kelas eksperimen. Aktivitas siswa di kelas kontrol ditunjukkan yaitu pada pertemuan pertama diperoleh 24,7\%, pertemuan kedua yaitu $32,4 \%$ dan pertemuan ketiga yaitu $39,4 \%$. Meskipun aktivitas pada kelas kontrol mengalami peningkatan tapi pada pertemuan I,II dan III persentasenya masih dalam kategori sangat kurang. Hal ini dikarenakan pada kelas kontrol hanya menerima informasi dan tidak terlibat langsung dalam pembelajaran sehingga siswanya cenderung pasif.

Berdasarkan hasil penelitian menunjukkan bahwa rata-rata nilai postes di kelas eksperimen $(68,62)$ lebih tinggi daripada rata-rata nilai postes kelas kontrol $(59,00)$. Sehingga dapat disimpulkan bahwa hasil belajar fisika menggunakan model pembelajaran berbasis masalah lebih baik daripada hasil belajar menggunakan pembelajaran konvensional. Hasil ini memberikan informasi bahwa ada pengaruh yang positif model pembelajaran berbasis masalah dalam meningkatkan hasil belajar fisika siswa.

Hal-hal yang dilakukan peneliti dalam kegiatan belajar mengajar menggunakan model pembelajaran berbasis masalahdengan mengikuti tahaptahap yaitu: Pada tahap orientasi siswa pada masalah (pertama), peneliti memotivasi siswa dan memfokuskan perhatian siswa, peneliti menyampaikan pentingnya materi pelajaran, prosedur pelaksanaan kegiatan belajar, dan hasil belajar yang dapat dicapai oleh siswa. Pada tahap mengorganisasi siswa untuk meneliti (kedua), penelitimembantu siswa mengorganisasikan tugas-tugas belajar terkait dengan permasalahan kemudian 
membagikan siswa ke dalam kelompok-kelompok belajar. Pada tahap penyelidikan individual maupun kelompok (ketiga), peneliti membagikan lembar kerja siswa untuk siswa sebagai pedoman dan membimbing siswamelakukan percobaan sebagai kegiatan untuk memahami materi lebih bermakna. Pada tahap mengembangkan dan mempresentasikan artefak dan exhibit (keempat), peneliti membantu setiap kelompok menyelesaikan dan menjawab semua permasalahan yang adaserta mempersentasikan hasil diskusi kelompok yang telah disiapkan, kemudian kelompok yang lain diberikan kesempatan memberikan pendapat atau masukan. Pada tahap menganalisis dan mengevaluasi proses mengatasi masalah (kelima), peneliti membantu siswa dalam mengkaji ulang pemecahan masalah sesuai dengan tujuan pembelajaran dan memberikan penguatan pada pemecahan masalah tersebut dan pada tahap ini peneliti membuat tes evaluasi untuk mengetahui pemahaman siswa.

\section{KESIMPULAN DAN SARAN}

\section{Kesimpulan}

Berdasarkan hasil analisis data penelitian dan uji statistik maka dapat disimpulkan hasil belajar fisika siswa dengan menggunakan model pembelajaran berbasis masalahsebelum diberikan perlakuan rata-rata pretes sebesar 18,12 dan setelah diberikan perlakuan diperoleh rata-rata postessebesar 68,62. Sedangkan siswa dengan model konvensional sebelum diberikan perlakuan ratarata pretes sebesar 19,62 dan setelah diberikan perlakuan rata- rata postes sebesar 59,00. Dari hasil uji hipotesis diperoleh $t_{\text {hitung }}>t_{\text {tabel, }}$, sehingga model pembelajaran berbasis masalah memiliki pengaruh terhadap hasil belajar siswa pada materi pokok Gerak Lurus di Kelas X SMA Negeri 11 Medan.

\section{Saran}

Berdasarkan hasil penelitian dan kesimpulan di atas, maka sebagai tindak lanjut dari penelitian ini disarankan beberapa hal yaitu (1) Hendaknya mengetahui cara mengelola kelas dan mengatur waktu agar semua sintaks model pembelajaran berbasis masalah dapat dilaksanakan dengan efektif saat pelaksanaan proses pembelajaran. (2) Hendaknya melakukan simulasi sebelum mencobakan model ini diterapkan terhadap siswa agar siswa lebih memahami dan terlatih dengan cara kerja model pembelajaran berbasis masalah ketika melakukan penelitian. (3) Hendaknya lebih memahami bagaimana menentukan masalah dan lebih berusaha untuk memotivasi siswa dalam memecahkan masalah kehidupan sehari-hari.

\section{DAFTAR PUSTAKA}

Arends, R. I.,(2008), Learning To Teach Edisi Ketujuh Buku Dua.Penerbit Pustaka Belajar, Yogyakarta

Djamarah dan Zain, (2006), Strategi Belajar Mengajar, Penerbit Rineka Cipta, Jakarta

Kharida, (2009),Penerapan ModelPembelajaranBerbasis Masalah Untuk Peningkatan Hasil Belajar Siswa Pada Pokok Bahasan Elastisitas 
Bahan, Jurnal Pendidikan

Fisika Indonesia 5:83-89

Pohan, A.F., (2012), Pengaruh ModelPembelajaran Berbasis Masalah Terhadap Hasil Belajar Siswa Pada Materi Pokok Listrik Dinamis Kelas IX SMP $N \quad 5$ Pematang Siantar T.P 2012/2013., Skripsi, FMIPA, Unimed, Medan.

Sudjana, (2005),MetodaStatistika. Penerbit Tarsito, Bandung.

Trianto,

(2009),MendesainModelPem belajaranInovatifProgresif: $K$ onsep,Landasandan implementasinyapada Kurikulum Tingkat Satuan Pendidikan,Penerbit Kencana,Jakarta

Yustina, (2009), Pengaruh Model Pembelajaran Berdasarkan Masalah Terhadap Hasil Belajar Fisika Siswa Pada Materi Pokok Gerak Lurus Di Kelas X SMA Negeri 3 Medan T.A 2009/2010., Skripsi, FMIPA Unimed, Medan 